\title{
A New Aceramic Neolithic Site Nearby the Obsidian Sources: Preliminary Insights from Sırçalıtepe
}

\section{Obsidiyen Kaynaklarının Yakınında Yeni Bir Akeramik Yerleşme: Sırçalıtepe’den İlk Gözlemler}

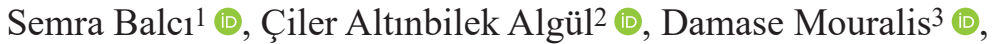 \\ Orkun Hamza Kaycı ${ }^{4}$, Ali Metin Büyükkarakaya ${ }^{5}$ @), Fazlı Açıkgöz 6 (1)
}

1/stanbul University, Faculty of Letters, Department of Archeology, Prehistoric Archeology, Istanbul, Turkey

${ }^{2}$ Istanbul University, Faculty of Letters, Department of Archeology Prehistoric Archeology, Istanbul, Turkey

3Université de Rouen, Laboratoire IDEES-UMR6266, Normandie, France

${ }^{4}$ Kütahya Dumlupınar University, Faculty of Arts and Sciences, Department of Archeology Prehistory, Kütahya, Turkey

${ }^{5}$ Hacettepe University, Department of Anthropology, Ankara, Turkey

${ }^{6}$ Niğde Museum (Retired Director), Niğde, Turkey

ORCID ID: S.B. 0000-0002-4944-7351;

C.A.A. 0000-0001-6420-940X

D.M. 0000-0001-7748-0258;

A.M.B. 0000-0002-7551-8440,

Corresponding author/Sorumlu yazar: Semra Balcı (Dr.),

İstanbul Üniversitesi, Edebiyat Fakültesi Arkeoloj Bölümü Tarih Öncesi Arkeolojisi, İstanbul, Türkiye E-posta: semrayildirimbalci@gmail.com

Submitted/Başvuru: 12.05.2021

Revision Requested/Revizyon Talebi: 11.06.2021 Last Revision Received/Son Revizyon: 18.06.2021 Accepted/Kabul: 19.06.202

Citation/Atıf: Balci, S., Altinbilek Algul, C., Mouralis, D., Kayci, O.H., Büyükkarakaya, A.M., \& Acikgoz, F. A New Aceramic Neolithic Site Nearby the Obsidian Sources: Preliminary Insights from Sirçalıtepe. Anadolu Araştırmaları-Anatolian Research, 24, 67-92 https://doi.org/10.26650/anar.2021.24.936778

\section{ABSTRACT}

This paper is a general assessment of the studies conducted in 2019 and 2020 at the site of Sirçalıtepe. The settlement, which is dated to the 8th mill BCE, is located in the Volcanic Cappadocia region, within the borders of the Kayırlı village in the province of Niğde. With its location, it can be characterised as the nearest site to the Göllüdağ and Nenezi Dağ obsidian sources in the region. The excavations at Sırçalıtepe were carried out in two different areas of the mound. One trench is the slope trench with documented architectural remains and finds related to daily life, and the other trench is from the top of the mound where obsidian knapping debris is present in proportions commonly seen in workshop areas. The architectural remains discovered in the slope trench involve mudbrick walls, lime plastered floors, and large ovens. However, the investigated area from the top trench with abundant cores and knapping debris reveals the difference between Sirçalıtepe and other contemporaneous sites in the region. Thus, it can be argued that Sırçalıtepe, especially with its obsidian artefacts, has the potential for revealing the relationship between the workshop and the site. Portable XRF analyses performed on a group of obsidian artefacts showed that the settlement inhabitants used Göllüdağ, Nenezi Dağ, and Acıgöl obsidian sources.

Keywords: Volcanic Cappadocia, Aceramic Neolithic, Mudbrick architect, Obsidian artefacts, Portables XRF analysis

\section{öz}

Makale, Sırçalıtepe yerleşmesinin 2019 ve 2020 yılı çalışmalarının genel değerlendirmesini içermektedir. MÖ 8. binyıl ortalarına tarihlendirilmekte olan yerleşme Volkanik Kapadokya bölgesinde, Niğde ili Kayırlı köyü sınırları içinde yer almaktadır. Bu konumu ile şimdilik bölgedeki Göllüdağ ve Nenezi Dağ obsidiyen yataklarına en yakın yerleşme özelliğini taşımaktadır. Yerleşmedeki kazı çalışmaları höyüğün iki farklı alanında yürütülmüştür. Bunlardan biri mimari kalıntıların ve gündelik yaşama ait buluntuların yer aldığı yamaç açması, diğeri ise işliklerde görülebilecek yoğunlukta obsidiyen yongalama atıklarının saptandığı zirve açmasıdır. Yamaç açmasında saptanan mimari kalıntılar kerpiç duvarlı ve kireç tabanlı yapı kalıntıları ve büyük boyutlu fıınlar ile tanımlanmaktadır. Zirve 
açmasında yer alan, obsidiyen yongalama atıklarının saptandığı alanının varlığı ise Sırçalıtepe'nin bölge yerleşmelerine göre farklılığını ortaya koymaktadır. Dolayısıyla Sırçalıtepe'nin, özellikle obsidiyen verileri ile, Volkanik Kapadokya Bölgesi'ndeki işlik yerleşme ilişkisini verebilecek potansiyele sahip olduğu söylenebilir. Yerleşmedeki obsidiyen buluntuların bir grubu üzerinde yapılan taşınabilir XRF analizleri yerleşme sakinlerinin Göllüdağ, Nenezi Dağ ve Acıgöl kaynaklarını kullandığını göstermektedir.

Anahtar Kelimeler: Volkanik Kapadokya, Akeramik Neolitik Dönem, Kerpiç mimari, Obsidiyen buluntular, Taşınabilir XRF analizi 


\section{Introduction}

Sırçalıtepe ${ }^{1}$ is located in the Değirmenyolu area of Kayırlı village in the modern town of Niğde. The site is situated in a favourable setting in the Volcanic Cappadocia region of Central Anatolia, and it lies about $3.5 \mathrm{~km}$ to the north of Göllüdağ and about $6.5 \mathrm{~km}$ to the southeast of Nenezi Dağ, approximately (Fig. 1). With this location, Sırçalıtepe is the Aceramic Neolithic settlement closest to the most exploited obsidian sources known so far in the region. The mound, which is 1408 meters above sea level, is about 12 meters high, being preserved in a size of $210 \times 170$ meters (Balc1 et al. 2018), while covering an area of 2.68 ha. The abundance of obsidian finds on the surface of the mound initially indicated its importance, which was later confirmed with the excavations that took place during 2019 and $2020 .^{2}$ Excavations have revealed a mid- $8^{\text {th }}$ millennium BCE settlement with well-preserved architectural features and chipped stone finds. The site is a good candidate to provide further insights into the mid- $8^{\text {th }}$ millennium BCE occupation in the region. In this paper, we present the environmental setting and archaeological background of the site, and furthermore focus on the results and research implications deriving from the two fieldwork seasons.

\section{Environmental Setting}

The Volcanic Cappadocia region was formed during the Miocene-Late Pleistocene period as a result of volcanic activities (Ercan 1986; Mouralis, Aydar, Türkecan and Kuzucuoğlu 2019a). The obsidian sources within the Göllüdağ and Nenezi Dağ volcanoes ${ }^{3}$ were formed during this period and are located nearby Sirçalıtepe. Located in the center of the Volcanic Cappadocia region, Göllüdağ is an acidic complex formation that was culminated during the Middle-Late Pleistocene (Mouralis 2003). The complex is about $12 \mathrm{~km}$ in diameter with a circular caldera shape. The Göllüdağ massif is about $1600 \mathrm{~m}$ in height and is made of rhyolitic domes. Nenezi Dağ is another rhyolitic dome located to the west of the Kayırl Corridor, west of the Göllüdağ massif (Erturaç, Okur and Ersoy 2017).

The volcanic character of the region resulted in the formation of acidic materials such as obsidian, rhyolite, tufa, pumice, and perlite. Volcanic clasts also contributed to the formation of alluvial areas in the region (Karabıyıkoğlu, Kuzucuoğlu, Pastre and Roberts 1997). The Göllüdağ massif is surrounded by the lowland alluvial areas within the Derinkuyu Plain to

1 The site was referred to as "Kayırlı Değirmenyolu" during the first studies (Balcı, Çakan ve Falay 2018) but later since it was learned that the local name of the area was Sirçalitepe, the name of the site was changed.

2 The abundance of obsidian on the top of the mound was first detected in 2016 and reported by the Niğde Museum, after which a systematic surface collection followed in the same year within the scope of the Niğde Prehistoric Survey Project. Current excavations continued under the directorate of the Niğde Museum and the scientific coordination of Assoc. Prof. Semra Balc1.

3 An obsidian outcrop is located about 100 meters to the southwest of the site. It is however unknown if it already outcropped when the site was occupied. Further geomorphological research around the site is planned to date this outcrop and understand its relationship to the site. 
the east and the Kayırl Corridor to the north (Both are approx. at an altitude of $1300 \mathrm{~m}$ ) (Mouralis et al. 2019a). Sirçalıtepe is an adjacent area to these alluvial areas.

The climatic changes and increasing humidity in the region during the Early Holocene had an impact on the human activity and formation of prehistoric settlements. The vegetation in Cappadocia during this humid period around 10,800-6700/6600 BP included various species, such as oak, pistacia, and juniper trees and meadow steppes (Roberts et al. 2001: 730; Kuzucuoğlu 2002: 37, 43; Woldring 2002: 63). Forests with oak (at an altitude of 1300 $\mathrm{m}$ ) and juniper trees (at an altitude of $1400 \mathrm{~m}$ ) covered the highlands (Woldring 1998: 106). In this respect, Göllüdağ must also have been covered with dense forests during this period. Sirçalıtepe, with its altitude of $1408 \mathrm{~m}$., should also have been similarly forested.

\section{Archaeological Background}

Previous research based on excavations and surveys in the Volcanic Cappadocia region yielded evidence concerning human mobility and the emergence of sedentary communities during the Early Holocene. The investigations of prehistoric obsidian workshops nearby obsidian outcrops ${ }^{4}$ (Balkan-Atl and Cauvin 1997; Binder and Balkan-Atl 12001) in particular provided substantial data on human mobility and interaction during this period. Excavations of the Kömürcü-Kaletepe obsidian workshop gave insights into the long-distance exchange with the Near East and Cyprus from the Pre-Pottery Neolithic to the end of the Chalcolithic Period (Binder and Balkan-Atl 12001; Balkan-Atl1 2003). During subsequent surveys in the region, various natural obsidian outcrops, workshops, and sites, which could be determined as campsites, were detected between the Kayırlı, Kömürcü, and Erikli Dere outcrops, which make the largest obsidian sources of Göllüdağ. The current evidence puts forth an intensive exchange of obsidian and related mobility of the prehistoric groups in the region (BalkanAtlı, Kayacan, Balcı, Astruc and Erturaç 2013).

The Early Holocene Aceramic Neolithic inhabitants of the region preferred locations near water sources and alluvial plains. There are only three sites in the region dating to the second half of the $9^{\text {th }}$ millennium where excavations have taken place. These are Aşıkl Höyük, founded on the western bank of the Melendiz River in Aksaray (Özbaşaran and Duru 2018; Quade, Stiner, Copeland, Clark and Özbaşaran 2018), the recently excavated Balıklı, located $14 \mathrm{~km}$ from Aşıklı in the same province (Kayacan, Goring-Morris, Duru, Özbaşaran in press), and Sofular Höyük near Kışlacık creek, a branch of the Halys River in Sofular Village in Nevşehir (Güngördü and Başoğlu 2019). The occupation at Aşıklı Höyük and Sofular Höyük spans into the $8^{\text {th }}$ millennium BCE and is followed by another site, Musular, which is a satellite-site of Aşıklı, dating to the mid- $8^{\text {th }}$ millennium BCE (Özbaşaran, Duru,

4 The workshops were first detected within the scope of the Cappadocia Obsidian Research Project during 19951996 (Balkan-Atlı and Cauvin 1997). 
Kayacan, Erdoğu and Buitenhuis 2012). Apart from these sites, Aceramic Neolithic levels belonging to the late $8^{\text {th }}$ millennium BCE were also found at Tepecik Çiftlik, located in the Çiftlik alluvial terrain (Çakan 2019); however, these levels have so far only been excavated in a limited area (Bıçakçı, Godon and Çakan 2012; Bıçakçı et al. 2017).

The mentioned sites procured obsidian from Göllüdağ, Nenezi, and Acıgöl sources while among these, Göllüdağ Kayırlı outcrops were most exploited. Chemical analysis revealed that the inhabitants of Musular, as well as those of Aşıklı Höyük, one of the most important sites for understanding the process of early sedentism in the region, procured obsidian dominantly from Göllüdağ (Gratuze and Boucetta 2006; Yıldırım-Balcı 2011a; Kayacan and Özbaşaran 2007; Astruc 2018; Kayacan and Altınbilek-Algül 2018). However, some technological connections between these sites and obsidian workshops have not yet been fully established. The local industries demonstrate that the use of obsidian from the Göllüdağ outcrops (Kayırlı Bitlikeler and Kömürcü) is followed in quantities by Nenezi Dağ obsidian (Gratuze and Boucetta 2006; Yıldırım-Balcı 2011a, Kayacan and Özbaşaran 2007, Kayacan and Altınbilek-Algül 2018) and finally Acıgöl, which was used in a smaller proportion (Kayacan and Altınbilek-Algül 2018). The preliminary results regarding chemical analysis of obsidian finds from Sofular Höyük also point out a dominant procurement of obsidian from the Göllüdağ Kayırlı outcrops and show less frequent use of Acıgöl obsidian (Karakoç 2019).

Previous studies showed that Cappadocian obsidian was circulated among the Near East (Cauvin and Chataigner 1998, Binder and Balkan-Atl 2001; Frahm and Tryon 2019; Frahm and Hauck 2017), but although the obsidian technology in Central Anatolian sites was related to the obsidian sources in the region, there is currently no evidence to attest to their direct role in the circulation and distribution of Cappadocian obsidian to other regions. ${ }^{5}$ It seems previously mentioned sites procured obsidian from other sources for their local consumption. However, within Central Anatolia, Kömürcü-Kaletepe Sector M is the only workshop that allows establishing a link between the contemporaneous sites and workshops based on technological features of the assemblages. Balkan-Atlı and Binder (2001) proposed that this workshop could have been involved in the production of the bifacial tools from Çatalhöyük, which is further supported by chemical analysis (Carter, Poupeau, Bressy and Pearce 2006). However, this is the sole example yielding data on the relationship between sources, workshops, and settlements in Central Anatolia. Thus, there is still a significant lack of data to understand the networks and links between settlements in the region and obsidian workshops, which could be overcome by comparisons that require detailed technological analysis aiming to reconstruct and understand obsidian chaînes opératoires.

5 Such comparisons require detailed technological analysis to understand the obsidian chaînes opératoires. 
In order to approach some of the above outlined issues, new excavations at Sirçalıtepe, located near obsidian outcrops, were initiated in 2019, providing already important data concerning the occupation in the mid- $8^{\text {th }}$ millennium cal. BCE. The site differs from its contemporaries in the region with its location and the abundance of obsidian artefacts and knapping debris on the top of the mound, which is in fact comparable to the volume of finds from the obsidian workshops in the nearby outcrops. Albeit being a settlement, the site resembles a workshop at the same time and could offer new information on the sourceworkshop-settlement relationship dynamics in the region during this period.

\section{Fieldwork, Architecture and Burial Customs}

Sırçalıtepe is surrounded with agricultural fields and is not currently densely inhabited. The top of the mound was being used for agriculture by the villagers, and the soil had been partially extracted, resulting in partial destruction of the upper cultural levels of the mound.

Excavations on the site were conducted in two consecutive seasons during 2019 and 2020. Fieldwork was focused on two main areas where the Aceramic Neolithic levels were reached (Fig. 2). The first area, the top of the mound, yielded a high number of obsidian artefacts. This sector was excavated in a $5 \times 10 \mathrm{~m}$ trench (Trench 6L). ${ }^{6}$ When deemed necessary, the area was subdivided into smaller grids of 1 x $1 \mathrm{~m}$, a useful system for the workshop excavations. In this area, the high volume of obsidian finds detected in the surface fill continued into lower levels (Fig. 3). Large pits filled with numerous obsidian artefacts and knapping debris were encountered. This led to the interpretation that the area was a midden filled with the debris from an obsidian workshop. The midden fill includes obsidian finds, as well as animal bones, and bone and groundstone tools, and the obsidian accumulations can be tracked from the section as well. Pits were dug into some architectural features, evidenced by the fragments of floor plaster and mudbricks (Balcı, Altınbilek-Algül and Mouralis in press).

The second excavation area is located on the eastern slope of the mound, which had been destroyed by the villagers during their soil extraction. Architectural features detected in this area (Trench 11J) allowed us to understand the built characteristics of the settlement (Balc1 et al. in press). Initially, a $6.5 \mathrm{~m}$ profile was made in the north-south direction to gain a better understanding of the stratigraphy. However, architectural elements (i.e., floor fragments and the remains of an oven) were encountered right below the surface soil in the western part of the trench, and the excavations in this area continued with a trench set up on the slope (Fig. 4). In this area, at least four building phases have so far been detected.

The uppermost architectural remains in the eastern slope are located in an area adjacent to the western profile. In the center, there is a large oven, extending into the western profile

6 Amorphous pottery sherds were found inside the surface fill. Among these, some pieces belong to the Middle Chalcolithic Period. 
of the trench. The oven was paved with large pebble stones and bordered with vertically placed stones. To the north of the oven, a white, lime-plastered floor and two pits were uncovered, all belonging to the same phase as the oven. However, an infant and a child were buried inside these pits. Inside one of the graves, a three-year-old child (SK3) was buried in a hocker position in the north-south direction. After the body was placed in the pit, it was covered with animal bones, including two scapulae of different bovines (Fig. 5), suggesting their intentional placement. Remains of an infant between the ages of 1.5-2 (SK4) were found inside the other grave. Although the context seems to have been destroyed, the human remains were found mixed with animal bones.

At this stage, a rectangular building with mudbrick walls (Building 1) was also found to the south of the oven. The northern and western walls of the building probably belonged to a renewal phase and were built on a well-preserved floor. The floor had at least two renewals: during the first phase, it was painted in red while the second one, it was made of a greycoloured material. The floor is partially destroyed in the interior of the building while it continues underneath the walls of Building 1 towards the south, merging with a channel that is unearthed in a limited area and a red-painted floor (Fig. 6, 7). The possible function of the channel requires further investigation; however, the accumulation inside may suggest its use as a water drainage channel. Analysis of the red-painted floor adjacent to the channel revealed the use of lime and the application of high temperature in the preparation of the floor plaster, pointing to pyrotechnology. ${ }^{7}$ The lime-plastered and red-painted floor and the drainage channel closely resemble the features of the $8^{\text {th }}$ millennium BCE special purposed buildings at Aşılılı Höyük (Özbaşaran 2013) and Musular (Özbaşaran et al. 2012) in the same region.

A burial pit was dug into the red-painted floor in this area (SK2), partially destroying the floor, confirmed because floor fragments were found inside the pit (Fig. 8). From the section of the deep pit, it could be observed that it was dug into two consecutive floor plasters, one of which belongs to an earlier phase. The body of a 35-40-year-old male was placed inside the pit in a hocker position. An obsidian blade was found inside the mouth of the individual, and a mudbrick block was placed on the body. The $\mathrm{C} 14$ sample obtained from the remains of this individual was dated between 7487-7253 cal BCE ( 2 sigma; 89,50\% probability) (Table 1).

The floor belonging to an earlier phase was cut by the SK2 burial pit and reaches a wall made with mudbrick blocks, which were preserved in five rows (Building 3). The mudbrick blocks were placed on top of a line of flat stones. To the north of this building, mudbrick debris from the wall of another rectangular building was also found (Building 2). This wall also has a stone foundation. These two possibly contemporaneous buildings were destroyed

7 Analyses of the floor plasters were conducted at the Mimar Sinan University, the Faculty of Fine Arts by Dr.

Ö. Ormanc1 with the initiation of Assoc. Prof. Dr. G. Duru. 
during the soil extraction by the villagers. Both structures were built on top of a burnt fill. In addition, another oven was excavated in an area close to the buildings although it remains unclear if the architectural features and the oven belong to the same level (Figure 10). However, another human burial was found in the lower levels of the burnt fill. The second C14 sample obtained from the remains of this individual dates this context into 7588-7498 cal BCE (2 sigma, 95,40\% probability).

In sum, the short period of excavations in a limited area yielded results that suggest the existence of an Aceramic Neolithic settlement at Sirçalıtepe with distinct renewal phases. The levels documented in the trench on the slope of the mound were C14 dated to the mid- $8^{\text {th }}$ millennium BCE.

\section{Obsidian Provenance Analyses and Technology}

The chipped stone assemblage from the site is represented by a single raw material, obsidian. Macroscopic evaluations reveal the presence of three distinct obsidian varieties: the grey-transparent (striped, smoky), semi-transparent/opaque greyish green (striped, smoky), and the opaque brown-black obsidian. Each variety was sampled, and pXRF sourcing analyses were conducted on a total of 13 obsidian flakes.

The obsidian artefacts were analysed using a portable X-ray fluorescence Thermo Scientific NITON XL3t analyser. The X-ray source of the analyser is a $50-\mathrm{kV}$ tube with an $\mathrm{Au}$ anode target. For the purpose of obsidian sourcing, the instrument was set to the "mining" mode, recording a wide range of elements: heavy metals, transitional metals, and light elements with each of the four beams. Each artefact is analysed for $60 \mathrm{~s}$ per beam giving a $240 \mathrm{~s}$ total time per sample. Attribution determined using the GeObs geological database, which includes more than 600 geological samples representing the sources and sub-sources in Anatolia (both Central and Eastern) and in the Caucasus (Mouralis et al. 2018). Detailed geochemical results and attribution are given in Table 2.

Obsidian flakes from Sirçalıtepe have Niobium $(\mathrm{Nb})$ content ranging between 10 and 20 ppm and low Zirconium ( $\mathrm{Zr}$ ) content, which is less than $80 \mathrm{ppm}$. These first observations point out the use of the "local" sources of obsidian, i.e., the Central Anatolian sources (Fig. 9). On a simple $\mathrm{Nb}$ versus Sr binary plot (Fig. 10), the artefacts are grouped into three clusters demonstrating the use of three different sources.

Attributing the artefacts to one of the sources known in Central Anatolia is a difficult task because of: i) the high number of different outcrops and ii) the chemical confusion between most of these outcrops located around the main rhyolitic volcanoes: Nenezi, Göllüdağ, and Acıgöl. If Nenezi is generally considered as one single source (including various obsidian outcrops), the situation is more complex in the case of the two other rhyolitic complexes. In 
the case of Acıgöl, we distinguish the "Eastern Acıgöl obsidian" emplaced during the main Acigöl eruption dated around $180 \mathrm{ka}$ and the obsidian associated with various monogenic vents, including Korudağ dome, emplaced around 20-10 ka (Mouralis, Pastre, Kuzucuoğlu, Türkecan and Guillou 2019b).

The Göllüdağ massif shows the most complex situation. It is formed by numerous coalescent domes, and most of them present obsidian outcrops (Mouralis, 2003). On the base of volcanological observation associated with high resolution LA-ICP-MS analyses, Binder et al. (Binder, Gratuze, Mouralis and Balkan-Atl 2011) grouped all the outcrops within the Göllüdağ massif in 8 chemical groups. However, in the present study, the use of a portable apparatus does not allow replicating such high-resolution distinction. We thus distinguish four main groups. Göllüdağ-East corresponds to the main exploited sources around Kömürcü and Erikli Dere (GDG-5 in Binder et al. 2011) and Bitlikeler-Ekinlik (GDG-4a and 4b). We also distinguish two Göllüdağ-West groups, respectively located north of Bozköy (GDG-1) and west of Kayırlı (GDG2). Finally, we group other outcrops within a single group that has been probably less exploited (GDG-3, top of Büyük Göllüdağ, GDG-7 in Sirça Deresi and GDG-6 west of Boztepe).

Table 2 shows the data involved in the study, and Figure 11 represents some of the plots used for the attribution of archaeological finds from Sırçalıtepe. Three artefacts (KDY5, 6 and 7), which are greyish green, semi-transparent to opaque, present high Strontium concentration (74-79 ppm) together with mid Rubidium (around $160 \mathrm{ppm}$ ) and low Niobium content (15-16 ppm). All these chemical characteristics indicate that the raw material of these artefacts comes from the Nenezi obsidian source.

Two other artefacts of a grey translucent obsidian (KDY11 and 12) show a lower Strontium concentration (around $60 \mathrm{ppm}$ ) with Rubidium and Niobium similar to the previous artefacts. These data, together with Barium and Zirconium content, are characteristics of Acıgöl East obsidians.

The third group includes the eight other artefacts with two macroscopic characteristics: KDY1 to KDY5b present a grey translucent obsidian whereas KDY9 and KDY10 derived from an opaque brown to black obsidian. All eight artefacts present low Strontium concentration (6 to $11 \mathrm{ppm}$ except for KDY1 with $17 \mathrm{ppm}$ ) together with higher Rubidium (177-198 ppm) and Niobium content (18.5-21.5 ppm). These artefacts also feature low Zirconium and Barium content. These characteristics point out to the main Göllüdağ-East group (GDG-4a, -4b, -5). Figure 11 indicates a possible confusion with the group "Göllüdağ other;" however, on the base of Rubidium (Fig. 11) or Thorium (Table 2) content, it appears that attribution to the Göllüdağ-East group is the most probable. 
The abundance of obsidian finds comes from the trench at the top of the mound (6L). The assemblage from this area includes a high number of bidirectional blade cores (Fig. 12) as well as knapping products and debris, suggesting that the cores were knapped on-site. All products and by-products of the knapping process are present within the assemblage. Furthermore, hammerstones that could have had been used for knapping as well as numerous obsidian tools were found in this area. The reduction of cores belongs to the bidirectional technology. It is of interest that the last blade removals on the cores have suitable forms for the production of arrowheads, given their pointed shape. Obsidian finds from the slope trench $(11 \mathrm{~J})$ are less numerous; however, they exhibit technological and typological similarities with the assemblage from the top of the mound. ${ }^{8}$ The lack of cores, on the other hand, poses difficulty in further comparisons.

Among the obsidian tools, there appear scrapers with various subtypes (Fig. 13), arrowheads (Fig. 14), and drills. Two mirror-like objects that were found on the surface and in the trench at the top of the mound are of further interest. Subtypes of the scrapers mostly include tools made on flakes, i.e., circular and semi-circular scrapers, fan-shaped scrapers, carinated scrapers, and end- and double-end scrapers. Similar examples to the circular and semi-circular scrapers made on thick flakes are also known from Aşıklı Höyük (YıldırımBalcı 2011a, Kayacan and Altınbilek-Algül 2018), Musular (Kayacan 2003), and Sofular Höyük (Karakoç 2019). Within the group of arrowheads, there are oval points with pressure retouch (Fig. 14) and an example with a steep retouch. Pressure retouch was applied mainly on the entire upper surfaces and partially near the ends. In some cases, the central parts of the upper surfaces were left without retouch. The pressure retouch oval arrowheads are similar to the examples found among the surface finds at Aşıklı (Yıldırım-Balcı 2011b, Kayacan and Altınbilek-Algül 2018), Musular (Kayacan 2003), and Tepecik-Çiftlik (Balcı 2019, Vinet and Guilbeau 2020). However, it is noteworthy that the Sırçalıtepe and Tepecik-Çiftlik (Balcı 2019) assemblages also contain arrowheads made with various decoration, which are incised on the ventral surfaces (Balc1 et al. in press).

\section{Ground Stone Tools}

As indicated by the initial surface collection, among the most abundant tool groups found at the site, ground stone tools follow the chipped stone artefacts in their quantities. Among ground stones, pounding tools, pestles, and hand-stones (Fig. 15) made of basalt and andesite were found mostly in a fragmented state. Some of these examples exhibit extensive usewear. A single example of a polisher and a sling missile were also found. During the surface collection at the mound, several grinding stones, mortars and pestles, hand-stones, and a grooved stone object were also recorded (Balc1 et al. 2018, 445: Figure 11).

8 Results of the technological analyses of obsidian finds are presented in more detail in Balc1 et al. in press. 


\section{Bone and Antler Tools}

Metapodials were among the most utilized animal body parts in bone tool production. However, scapulae and ribs were also used. Among the tool types, bone awls are in the majority. A bone needle and a spatula fragment were also documented (Fig 16). The central part of the needle found in the slope trench has an oval section and its surface was formed with good craftsmanship. Its upper extremity is wider with a rectangular section and a semioval form. Two antler tools were also found at the site. One of the antler tools has a rounded tip and has been interpreted as a pressure-flaking tool. Such tools are known to have been used in pressure retouch making. The presence of pressure retouched obsidian arrowheads at the site further corroborates this interpretation.

\section{Animal Remains}

Preliminary studies of the animal remains indicate the dominance of domesticated sheep/ goat, followed by cattle. Other species include boar, deer, horse, hare, fox, and bird species as well as reptilians. The zooarchaeological remains attest to the consumption of a wide range of different animal species for nutritional purposes. Among the studied material, bones belonging to the dorsal part of the animals, which are the meatiest parts, were present. Cranial elements and tarsal bones are less represented than the long bones. Butchering marks have been observed on some bones, as well as slight burning and gnawing traces.

\section{Discussion and Conclusion}

Two seasons of fieldwork at Sırçalıtepe have confirmed the site's potential to further understand the $8^{\text {th }}$ millennium BCE Aceramic Neolithic communities in Volcanic Cappadocia. Available evidence indicates that the site is the closest settlement to Göllüdağ and Nenezi Dağ, the most extensively exploited obsidian sources in the region. This may in part explain the abundance of obsidian finds on the top of the mound. Furthermore, the volume of obsidian artefacts on the surface adheres closely to the pattern observed in workshops, and the chipped stone elements found during excavations confirm that the site had also been used as a workshop, at least during the later phases. Thus, Sirçalıtepe could be defined as a settlement as well as a workshop. Indeed, knapping products of the site's workshop were extensively used within the settlement; however, it is still unclear if these products were exported to other settlements, which is a question to focus on in subsequent studies.

Apart from the obsidian sources, the proximity of Sirçalitepe to alluvial terrains and forests should have influenced the inhabitant's preference of this area to settle down for their subsistence strategies. Although the arrowheads could not be straightforwardly linked to hunting activities only, their abundance and variety on the site, as well as the presence of wild animal species suggest the importance of hunting. Sirçalıtepe belongs to the $8^{\text {th }}$ millennium 
$\mathrm{BCE}$, a period when agricultural activities increased. This may explain its location near the alluvial plains; however, studies focusing on the ratio of agricultural activities at the site are ongoing.

Among the $8^{\text {th }}$ millennium BCE sites in the region, Musular and Aşılkl Höyük display close similarities with Sirçalıtepe. Especially the mudbrick architecture, the red-painted floor, and, although constructed with a different technique, the channel are among the architectural similarities between these sites. Obsidian assemblages show further similarities. The raw materials of the obsidian assemblages from all three sites were intensively procured from the Göllüdağ Kayırlı outcrops. From a technological point of view, bidirectional technology dominates the chipped stone industry during the upper levels at Aşıklı Höyük (YıldırımBalc1 2011a; Kayacan and Algül 2018; Kayacan 2014) as well as at Musular (Kayacan 2003) and Sirçalıtepe. However, the core types linked to this technology show some goal-oriented diversities. In this regard, the majority of the cores from Surçalıtepe adhere more closely to the Musular examples (Kayacan 2018). The knapping was oriented towards the production of blades and blade-like flakes for the making of pressure retouched arrowheads. Sirçalitepe as well as Musular has yielded numerous examples of these arrowheads.

Finally, the location of Sirçalıtepe near the obsidian sources, the rich and diverse obsidian assemblage from the site, and the abundance of knapping products of bidirectional technology that indicate on-site knapping all point to the site's importance in providing answers to the key questions on the Neolithisation process in Volcanic Cappadocia. Future work at the site will focus on understanding the source-workshop-settlement relationship dynamics in Central Anatolia and the role of Sirçalıtepe among the $8^{\text {th }}$ millennium BCE sites in Volcanic Cappadocia.

Peer-review: Externally peer-reviewed.

Conflict of Interest: The author has no conflict of interest to declare.

Grant Support: This study was funded by the Scientific Research Project Coordination Unit of Istanbul University. Project Number: SBA-2019-34411.The excations are supported by the Republic of Turkey Ministry of Culture and Tourism and the General Directorate for Cultural Heritage and Museums.

Acknowledgement: Excavations at Sırçalıtepe were conducted under the directorate of the Niğde Museum with the permission of the Republic of Turkey Ministry of Culture and Tourism and the General Directorate for Cultural Heritage and Museums. We are grateful to Murat Tektaş and all of the Niğde museum staff for their helpfulness. We would like to thank Okan Aslaner, Ozan Özbudak, Banu Öksüz, Volkan Manap, Yasin Gökhan Çakan, Hale Tümer, Sera Yelözer, and Bogdana Milić for their help and support during different phases of this work. We also sincerely thank our students (Ecem Kızıltaş, Şevval Şirin, Kübra İren, Burcu Alpagut, Ayber Alper, Mustafa Gökçen, and Mert Erdoğan) for their work in the field and lab. We would also like to thank the Istanbul University Scientific Research Project Unit for sponsoring this study (BAPSIS Project No SBA-2019-34411). 


\section{References}

Astruc L. (2018). Obsidian Use during the Level 4 Occupations at Aşıklı Höyük. In M. Özbaşaran, G. Duru, \& M. Stiner (Eds.), The Early Settlement at Aşıklı Höyük- Essays in Honor of Ufuk Esin (pp.345-362). Ege yayınları, İstanbul.

Balc1, S. (2019). The Obsidian Industry of Pre-Pottery Neolithic Levels at Tepecik-Çiftlik, Central Anatolia. In Astruc, L, McCartley C., Briois, F, Kassianidou V. (Eds.), Near Eastern Lithic Technologies on the move. Interactions and Contexts in Neolithic Traditions (235-246). Astrom Editions, Nicosia.

Balcı, S., Altınbilek-Algül, Ç. \& Mouralis, D. (in press). Sırçalıtepe: A New Aceramic Neolithic Site in Volcanic Cappadocia (Central Anatolia). The 9 th International Conference on PPN Chipped and Ground Stone Industries of the Near East 2019, Tokyo.

Balcı, S., Çakan, Y. G. \& Falay, B. (2018). Niğde Tarihöncesi Yüzey Araştırmaları 2016. 35. Araştırma Sonuçları Toplantısı - 2. Cilt, 427-446.

Balkan-Atl, N. (2003). Obsidien "Ticareti”: Yeni Veriler, Yeni Modeller, Yeni Sorunlar. Bir Deneme. In M. Özbaşaran, O. Tanındı, \& A. Boratav (Eds.), Archaeological essays in honour of Homo amatus : Güven Arsebük (pp.9-18). Ege yayınları, İstanbul.

Balkan-Atlı, N. \& Binder, D., (with contrubition Beugnier, V., Buitenhuis, H., Kuzucuoğlu, C., Mouralis, D., Slimak, K., Thery, I.) (2001). Les ateliers de taille d'obsidienne. Fouille de Kömürcü-Kaletepe 2000, Anatolia Antiqua IX, 193-205.

Balkan-Atlı, N. \& Cauvin, M. C. (1997). 1995 Yılı Aksaray, Niğde, Nevşehir İlleri Obsidien Yüzey Araştırması. XIV. Araştırma Sonuçları Toplantısı -I, 293-312.

Balkan-Atlı, N., Kayacan, N., Balc1, S., Astruc, L., \& Erturaç, K. (2013). Göllü Dağ Obsidian Project. In F. Borrelli Tena, J. J. Ibáñez-Estévez, \& M. Molist Montañà (Eds.), Stone Tools in Transition: From HunterGatherers to Farming Societies in the Near East (pp. 456-474). Servei de Publicacions de la Universitat Aut $\tilde{A}^{2}$ noma de Barcelona.

Bıçakçı, E., Godon, M., Büyükkarakaya, A.M., Erturaç, K., Kuzucuoğlu, C., Çakan, Y.G. \& Vinet, A. (2017). Les fouilles de Tepecik-Çiftlik et les activités du programme Melendiz préhistorique, campagne 2016. Anatolia Antiqua XXV, 71-94.

Bıçakçı, E., Godon, M. \& Çakan, Y.G. (2012). Tepecik-Çiftlik. In M. Özdoğan, N. Başgelen, \& P. Kuniholm (Eds.), The Neolithic in Turkey, Central Turkey 3 (pp. 89-134). Archaeology and Art Publications, İstanbul.

Binder, D. \& Balkan-Atl1, N. (2001). Obsidian exploitation and blade technology at Kömürcü-Kaletepe (Cappadocia, Turkey). In I. Caneva, C. Lemorini, D. Zampetti, \& P. Biagi (Eds.), Beyond tools : redefining the PPN lithic assemblages of the Levant (pp.1-16). Ex oriente, Berlin.

Binder, D., Gratuze, B., Mouralis, D. \& Balkan-Atl1, N. (2011). New investigations of the Göllüdağ obsidian lava flows system: a multidisciplinary approach. Journal of Archaeological Science 38: 3174-3184.

Carter, T., Poupeau, G., Bressy, C. \& Pearce, N.J.G. (2006). A new programme of obsidian characterization at Çatalhöyük, Turkey. Journal of Archeological Science 33, 893-909.

Cauvin, M.-C. \& Chataigner, C. (1998). Distribution de l'obsidienne dans les sites archéologiques du Proche et Moyen Orient. In M.C. Cauvin, A. Gourgaud, B. Gratuze, N. Arnaud, G. Poupeau, J. L. Poidevin, \& C. Chataigner (Eds.), L'obsidienne au Proche et Moyen Orient ancien: du volcan à l'outil (pp. 325-350). BAR International Series 738, Archaeopress, Oxford. 
Çakan, Y.S. (2019). Neolitik Dönem'de Yeni Bir Yapı Tipi: Tepecik-Çiftlik’te “Fırınlı Yapılar”. In P. Çaylı, I. Demirtaş, B. Eser (Eds.), Arkeolojiyle Geçen Yarım Asır: Sevil Gülçur Armağanı, Prof. Dr. Sevil Gülçur adına Anı Kitabı (pp. 649-659). Bilgin Kültür Yayınları, Ankara.

Ercan T. (1986). Orta Anadolu'daki Senozoyik Volkanizması. MTA Dergisi 107, 119-140.

Erturaç, M. K., Okur, H. \& Ersoy, B. (2017). Göllüdağ Volkanik Kompleksi İçerisinde Kültürel ve Jeolojik Miras Öğeleri. Türkiye Jeoloji Bülteni. Cilt 60, Sayı 1, 17-34.

Frahm, E. \& Hauck, T. C. (2017). Origin of an obsidian scraper at Yabroud Rockshelter II (Syria): Implications for Near Eastern social networks in the early Upper Palaeolithic. Journal of Archaeological Science: Reports 13, 415-427.

Frahm, E. \& Tryon, C. A. (2019). Origin of an Early Upper Paleolithic obsidian burin at Ksar Akil (Lebanon): Evidence of increased connectivity ahead of the Levantine Aurignacian? Journal of Archaeological Science Reports 28, 1-14.

Gratuze, B. \& Boucetta, S. (2006). Déterminationde l'origine de lamelles en obsidienne trouvée sur les sites de Musular, Çayönü, Aşıklı, Çakılbaşı et MersinYumuktepe (Turquie) (Unpublished report).

Güngördü, F. V. \& Başoğlu, O. (2019). Kızılırmak Nehri Kenarında Bir Çanak Çömleksiz Neolitik Dönem Yerleşmesi: Sofular Höyük. Olba XXVII, 41-60.

Gratuze, B. \& Boucetta, S. (2006). Déterminationde l'origine de lamelles en obsidienne trouvée sur les sites de Musular, Çayönü, Aşıklı, Çakılbaşı et MersinYumuktepe (Turquie) (Unpublished report).

Karabıyıkoğlu, M., Kuzucuoğlu, C., Pastre, J. F. \& Roberts, H. (1997). Excursion Guide to the Konya Plain and Cappadocia. INQUA, Symposium on the Late Quaternary in the Eastern Mediterranean, April 1997, Ankara.

Karakoç, M. (2019). Sofular Yontmataş Buluntu Topluluğu. (Unpublished Ph.D Thesis). Gazi University, Institute of Social Sciences, Ankara.

Kayacan, N. (2003). Chipped Stone Indusrty of the Neolithic Site of Musular (Cappadocia): Preliminary Results. Anatolia Antiqua XI, 1-10.

Kayacan, N. (2014). Aşıklı Obsidiyen İşçiliği ve Yerleşme Analizi. Yerleşim Sistemleri ve Mekan Analizi, TAS 1, 137-144.

Kayacan, N. (2018). Oval Points and Cattle-Hunting Practices in Central Anatolia during the 8th Millennium BC. Adalya 21, 45-61.

Kayacan, N. \& Atınbilek-Algül, Ç. (2018). Aşıklı Höyük Obsidian Studies: Production, Use and Diachronic Changes. In M. Özbaşaran, G. Duru, \& M. Stiner (Eds.), The Early Settlement at Aşıkl Höyük-Essays in Honor of Ufuk Esin (pp. 363-382). Ege yayınlar1, İstanbul.

Kayacan, N., Goring-Morris, A.N., Duru, G. \& Özbaşaran, M. (in press). A Prehistoric Survey in Cappodocia and a New Early Holocene Site, Balıkl: Preliminary Insights into the locaş chipped stone industries. The 9 th International Conference on PPN Chipped and Ground Stone Industries of the Near East 2019, Tokyo.

Kayacan N. \& Özbaşaran, M. (2007). The Choice of Obsidian and its Use at Musular, Central Anatolia. In L. Astruc, D. Binder, F. Briois (Eds.), Systemes techniques et communautés du néolithique précéramique au ProcheOrient Technical Systems and Near Eastern PPN Communities (pp.229-233). édition APDCA, Antibes.

Kuzucuoğlu, C. (2002). The environtemal frame in Central Anatolia from the 9 the to the 6 th millennia cal B.C. In F. Gérard- L. Thissen (Eds.) The Neolithic of Central Anatolia, Proceeding of the International CANeW Table Ronde (pp. 33-58). Ege Yayınları, İstanbul. 
Mouralis, D. (2003). Les complexes volcaniques quaternaires de Cappadoce (Göllüdağ et Acıgöl)- Turquie: évolutions morphodynamiques et implications environnementales, Universite Paris 12- Val de Marne, UFR des Letters et Sciences humaines- Département de Géographie, Laboratoire de Géographie Physique (UMR 8591) (Unpublised Doctorat Thésis), Paris.

Mouralis, D., Aydar, E., Türkecan, A. \& Kuzucuoğlu, C. (2019a). Quaternary Volcanic Landscapes and Prehistoric Sites in Southern Cappadocia: Göllüdağ, Acıgöl and Hasandağ. In C. Kuzucuoğlu, A. Çiner, \& N. Kazanc1 (Eds.), Landscapes and Landforms of Turkey. World Geomorphological Landscapes (pp. 551-563). Springer, Cham.

Mouralis, D., Pastre, J.-F., Kuzucuoğlu, C., Türkecan, A. \& Guillou, H. (2019b). Tephrostratigraphy and chronology of the Quaternary Gölludağ and Acıgöl volcanic complexes (Central Anatolia, Turkey). Med. Geosc. Rev. 1: 179-202. https://doi.org/10.1007/s42990-019-00010-8

Mouralis, D., Massussi, M., Palumbi, G., Akköprü, E., Balossi Restelli, F., Brunstein, D., Frangipane, M., Gratuze, B., Mokadem, F. \& Robin, A.-K (2018). The procurement of obsidian at Arslantepe (Eastern Anatolia) during the Chalcolithic and Early Bronze Age: Connections with Anatolia and Caucasus. Quaternary International 467: 342-359. https://doi.org/10.1016/j.quaint.2017.11.041

Özbaşaran, M. (2013). Orta Anadolu'nun Neolitikleşme Sürecinde Aşıklı. Colloquium Anatolicum XII: 1-14.

Özbaşaran, M., Duru, G., Kayacan, N., Erdoğu, B. \& Buitenhuis, H. (2012). Musular: The 8th Millenium cal. BC Sattelite Site of Aşıklı. In M. Özdoğan, N. Başgelen. P. Kuniholm (Eds.) The Neolithic in Turkey, Central Turkey (pp.159-180). Archaeology and Art Publications, İstanbul.

Özbaşaran, M. \& Duru, G. (2018). Introduction to the Aşıklı Höyük Project. In M. Özbaşaran, G. Duru, \& M. Stiner (Eds.), The Early Settlement at Aşıklı Höyük- Essays in Honor of Ufuk Esin (pp. 1-14). Ege yayınları, İstanbul.

Quade, J., Stiner, M. C., Copeland, A., Clark, A. E. \& Özbaşaran, M. (2018). Summary of Carbon-14 Dating of the Cultural Levels of Aşıklı Höyük. In M. Özbaşaran, G. Duru, \& M. Stiner (Eds.), The Early Settlement at Aşıklı Höyük- Essays in Honor of Ufuk Esin (pp. 43-56). Ege yayınları, İstanbul

Roberts, N, Reed, J.M., Leng, M.J., Kuzucuoğlu, C. , Fotugne, M., Bertaux, J., Woldring, H., Bottema, S., Black, S., Hunt, E. \& Karabıyıkoğlu, M. (2001). The tempo of Holocene climatic change in the eastern Mediterranean region: new high-resolution crater-lake sediment data from central Turkey. Holocene 11, 721-736.

Vinet, A. \& Guilbeau, D. (2020). Obsidian on the Move: From the sources to the tool. The Case of TepecikÇiftlik (Turkey) around $6000 \mathrm{BC}$ ). In A. Otto, M. Herles and K. Kaniuth (Eds.), 11 ICAANE Proceedings of the 11 th International Congress on the Archeology of the Ancient Near East (pp.91-104), volume 1, Harrassowitz Verlag, Wiesbaden.

Woldring, H. (1998). A Pollen Diagram From a River Sediment in Central Anatolia. TÜBA-AR 1, 105-111, Ankara.

Woldring, H. (2002). Climate Change and the onset of Sedentism in Cappadocia. In F. Gérard, L.

Thissen (Eds.) The Neolithic of Central Anatolia, Proceeding of the International CANeW Table Ronde (pp. 60-66). Ege Yayınları, İstanbul.

Yıldırım-Balc1, S. (2011a). Aşıklı Höyük Obsidiyen Teknolojisi. TÜBA-AR 14, 19-39.

Yıldırım-Balcı, S. (2011b). The Typological Analysis of Aşıklı Arrowheads and Problems. In E. Healey, S. Campbell, O Maeda (Eds.) The State of the Stone Terminologies, Continuities and Contexts in Near Eastern Lithics, Studies in Early Near Eastern Production, Subsistence, and Environment 13 (pp. 411415). Ex Oriente, Berlin. 


\section{Figures and Tables}

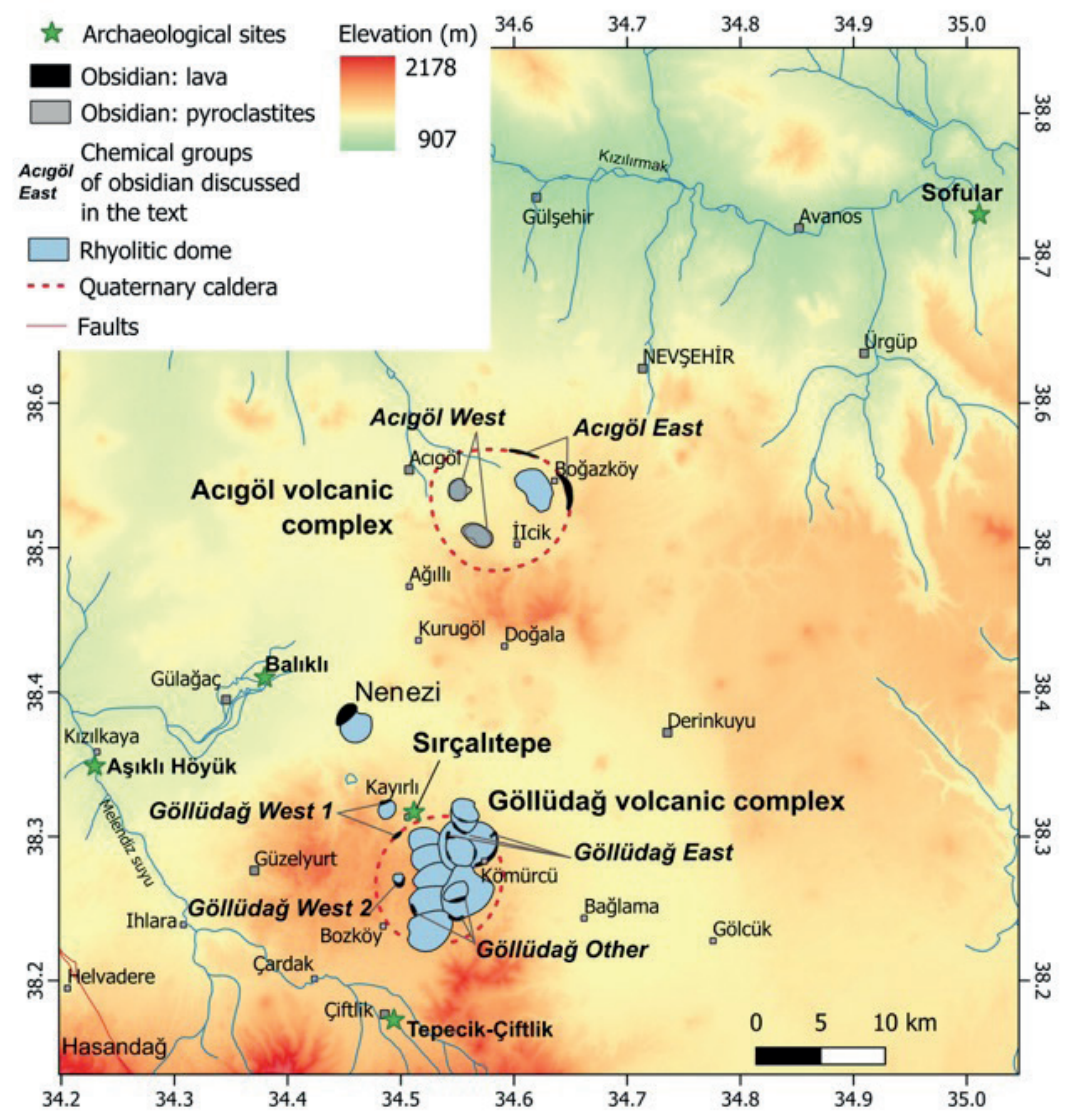

Figure 1. Location of Sirçalıtepe and the main prehistoric settlements, obsidian sources and workshops (prepared by D. Mouralis). 


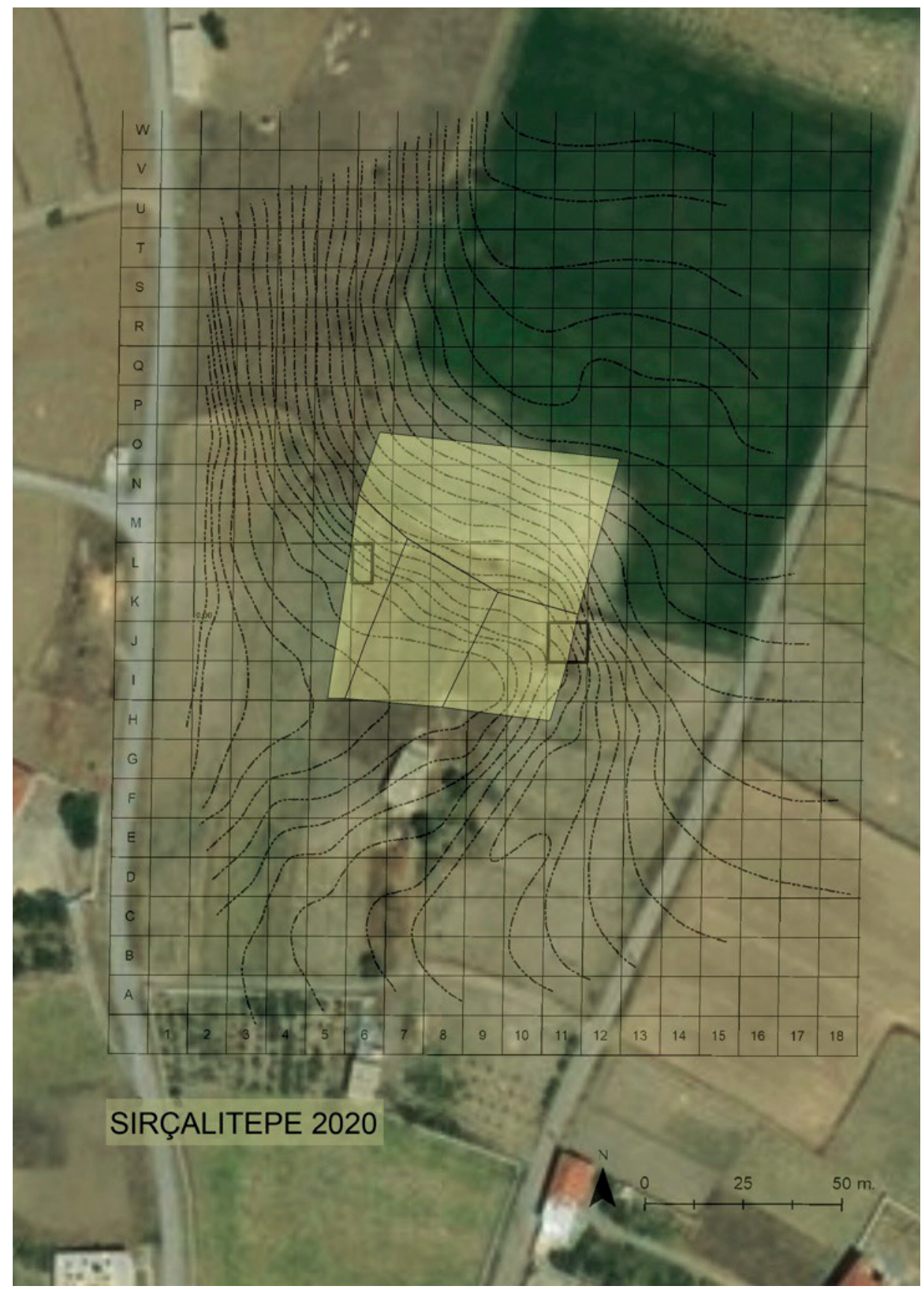

Figure 2. Topography of the site and the location of trenches (prepared by Y.G. Çakan). 


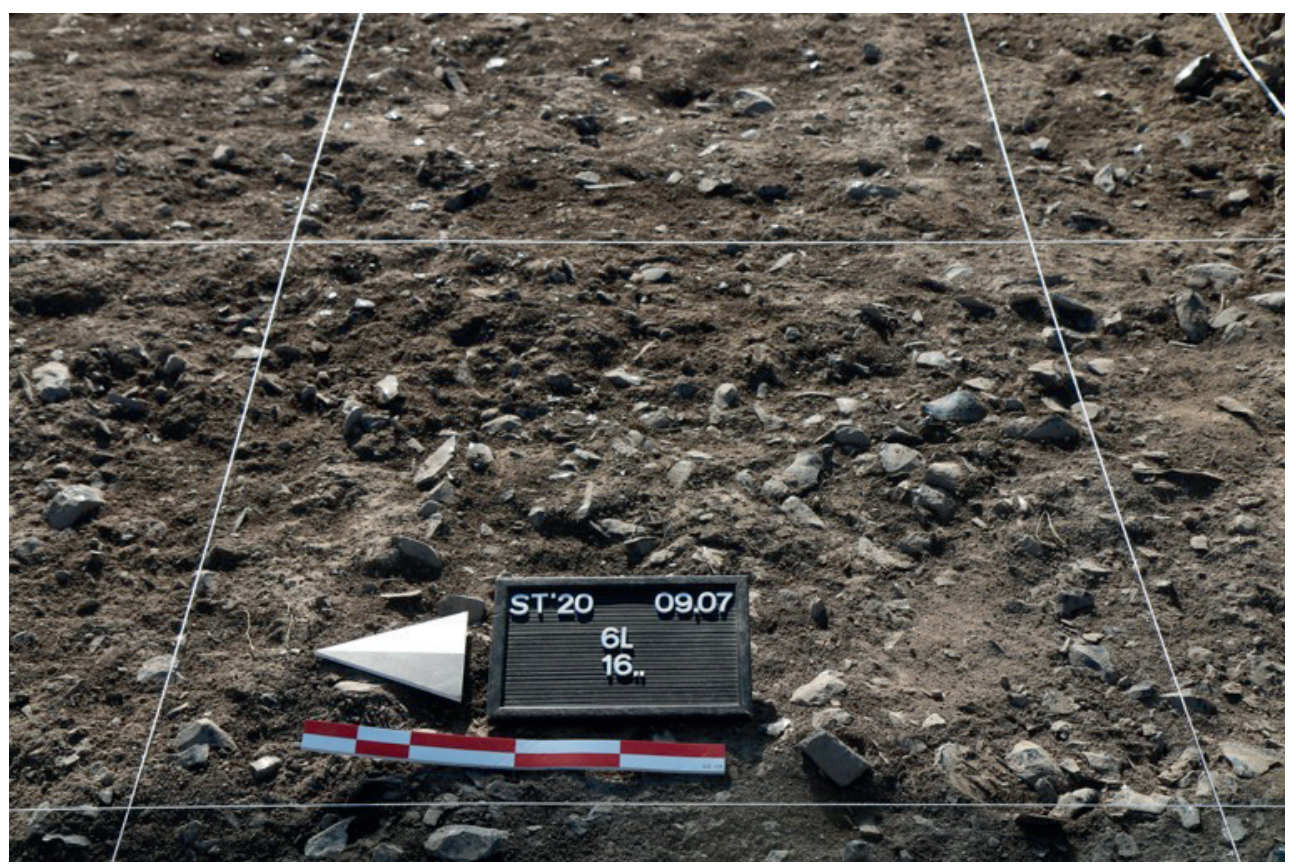

Figure 3. Trench $6 \mathrm{~L}$ showing the mass of obsidian artefacts.

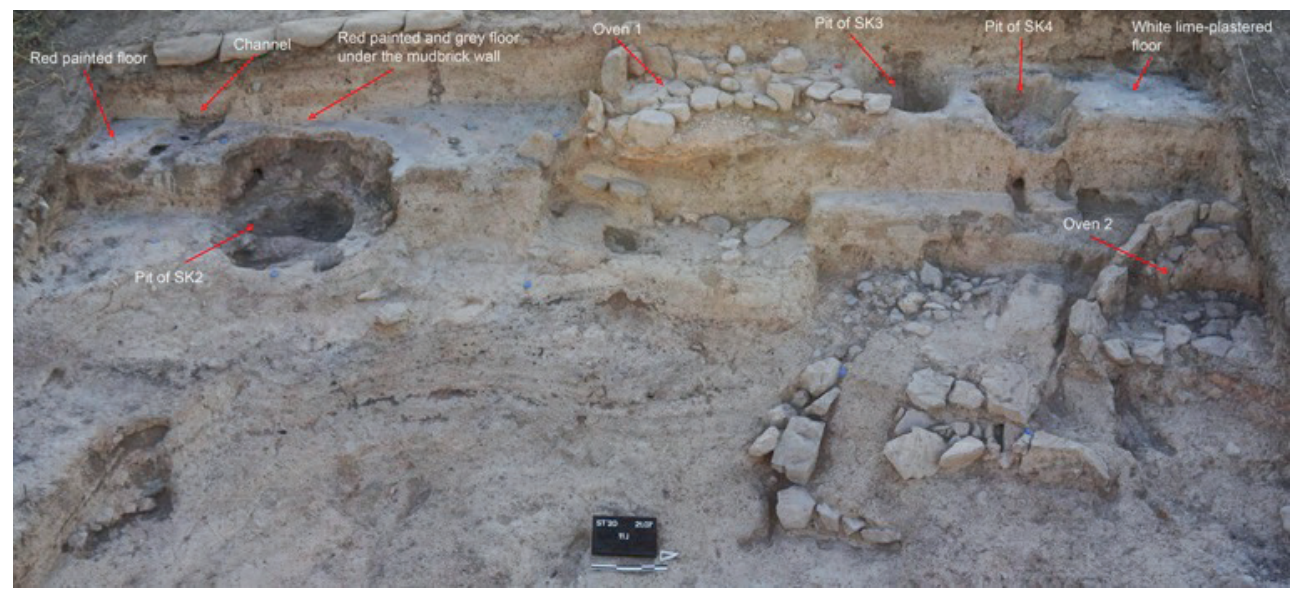

Figure 4. View of trench $11 \mathrm{~J}$ from the east. 


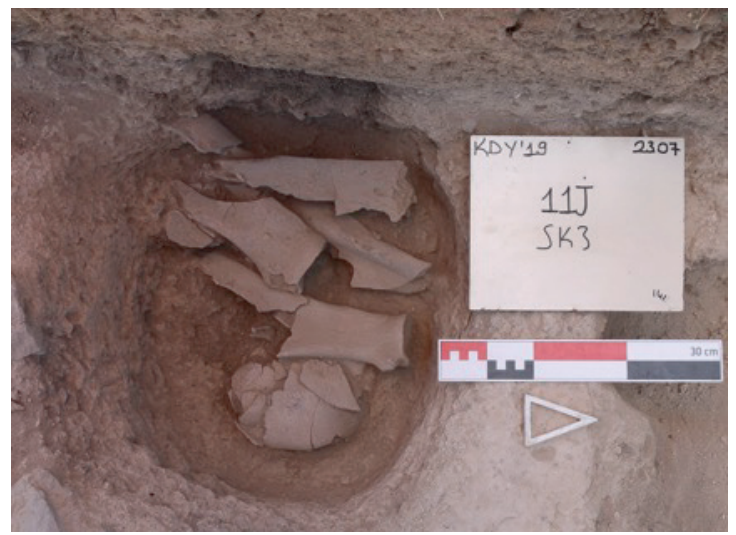

Figure 5. Child burial with scapulae of bovines (SK 3).

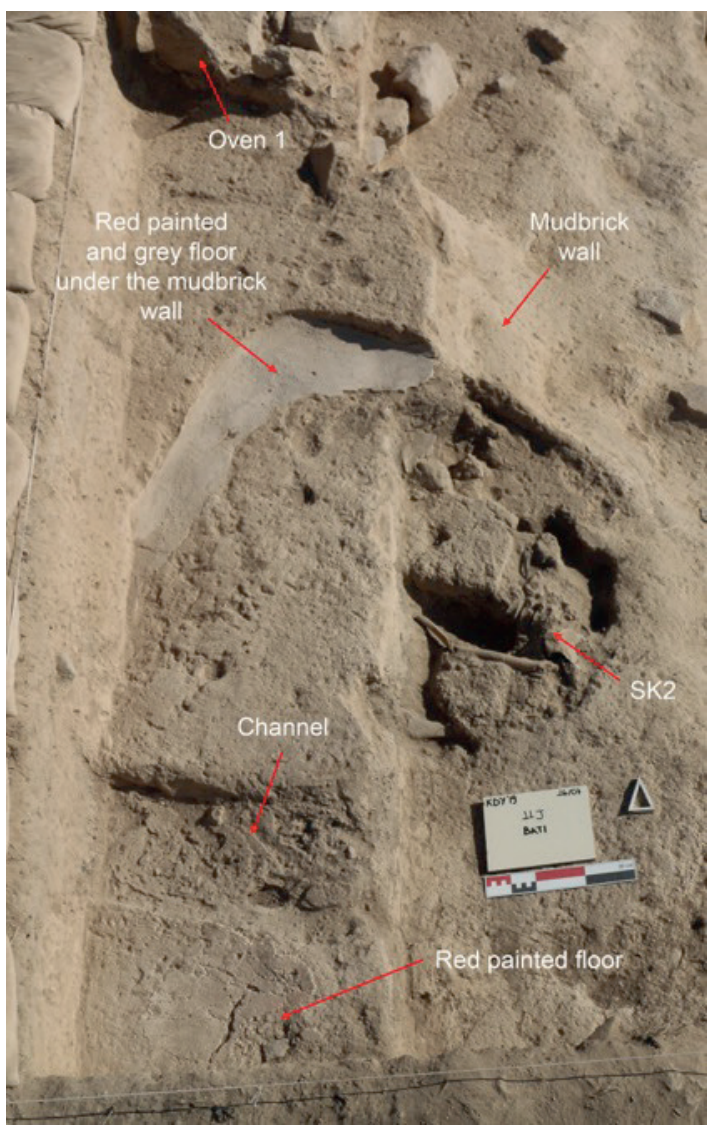

Figure 6. Overview of red painted floor, channel and burial pit (SK 2). 


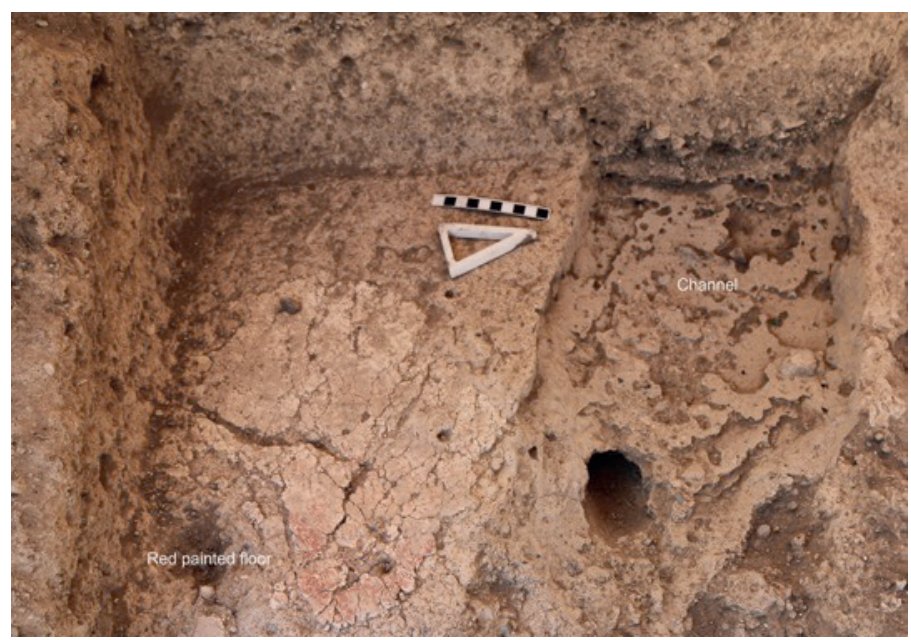

Figure 7. Close up red painted floor and channel.

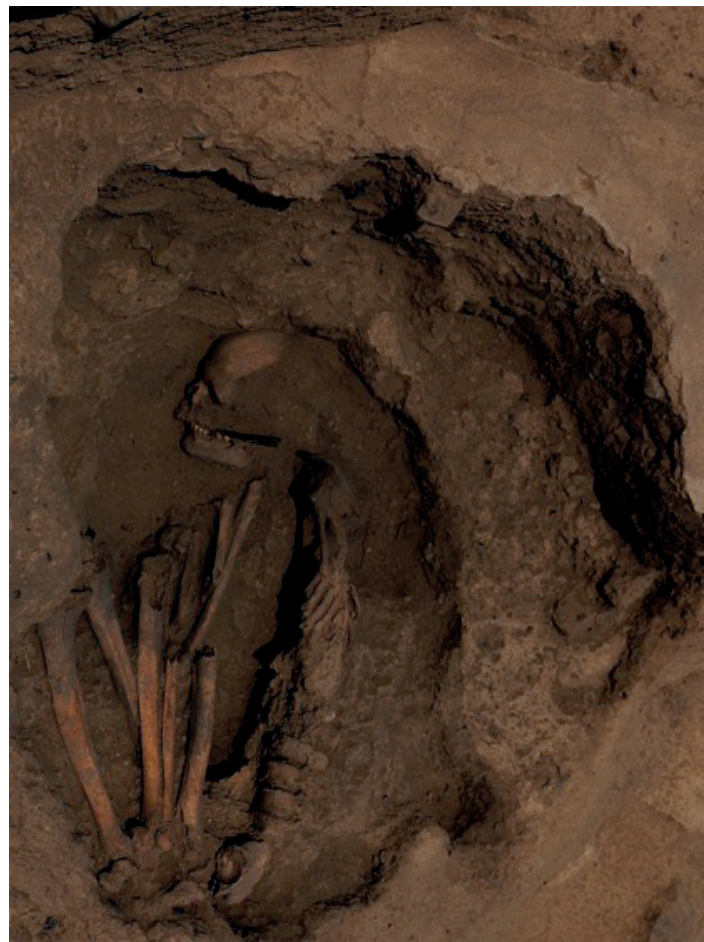

Figure 8. Individual (SK2) inside the burial pit. 


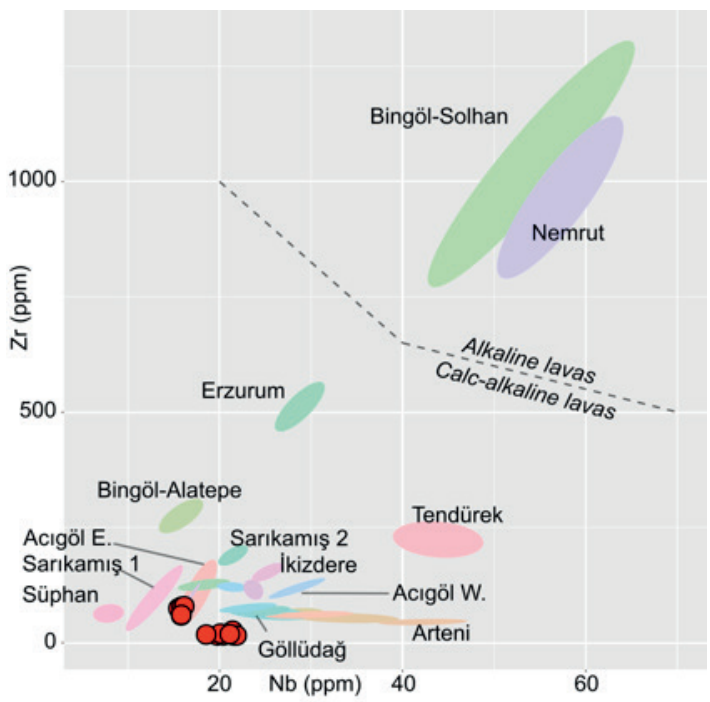

- Artefacts retrieved in Sırcalıtepe

Figure 9. $\mathrm{Nb} / \mathrm{Zr}$ plot showing the artefacts retrived in Sırçalıtepe compared to some geological sources (GeObs Database).

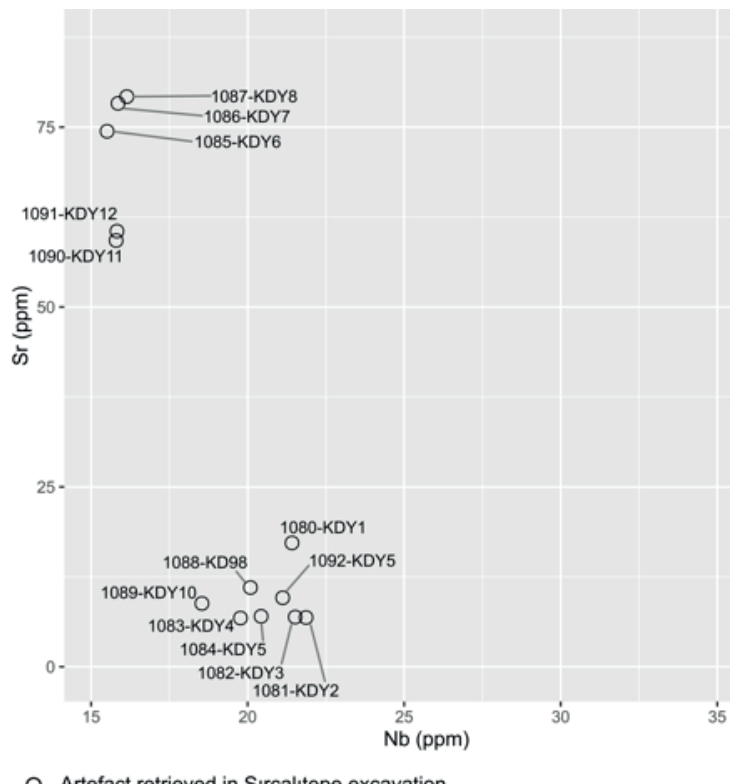

Figure 10. Rb/Sr plot showing the 13 artefacts retrieved in Sirçalıtepe forming three clusters corresponding to three geological sources. 

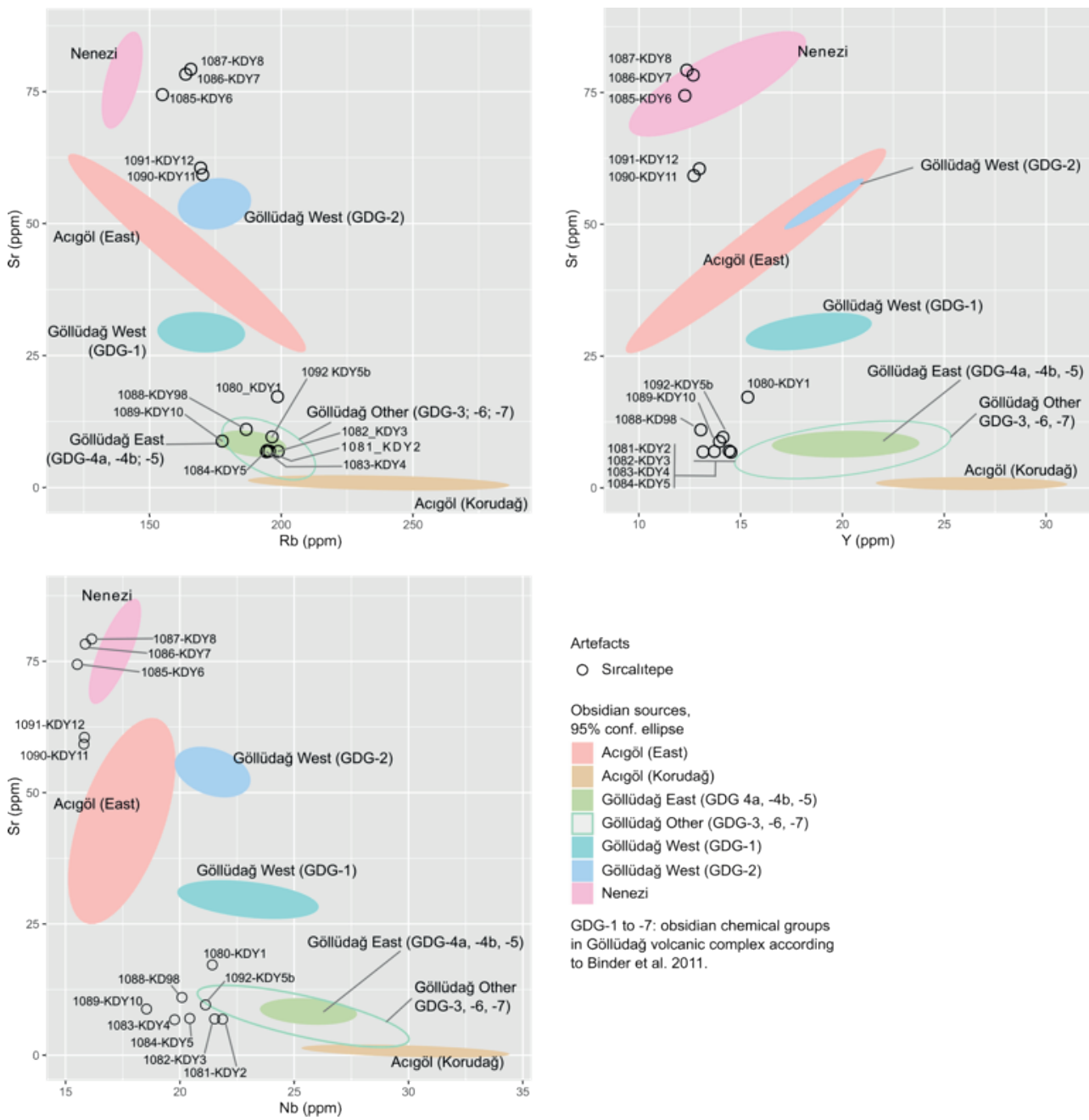

Artefacts
O Sircalitepe

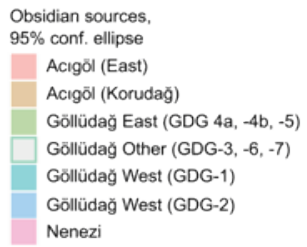

GDG-1 to -7: obsidian chemical groups in Göllūdağ volcanic complex according to Binder et al. 2011.

Figure 11. $\mathrm{Rb} / \mathrm{Sr}, \mathrm{Y} / \mathrm{Sr}$ and $\mathrm{Nb} / \mathrm{Sr}$ plot showing the 13 artefacts compared to the geographical sources of Cappadocia (Göllüdağ, Nenezi and Acıgöl). 

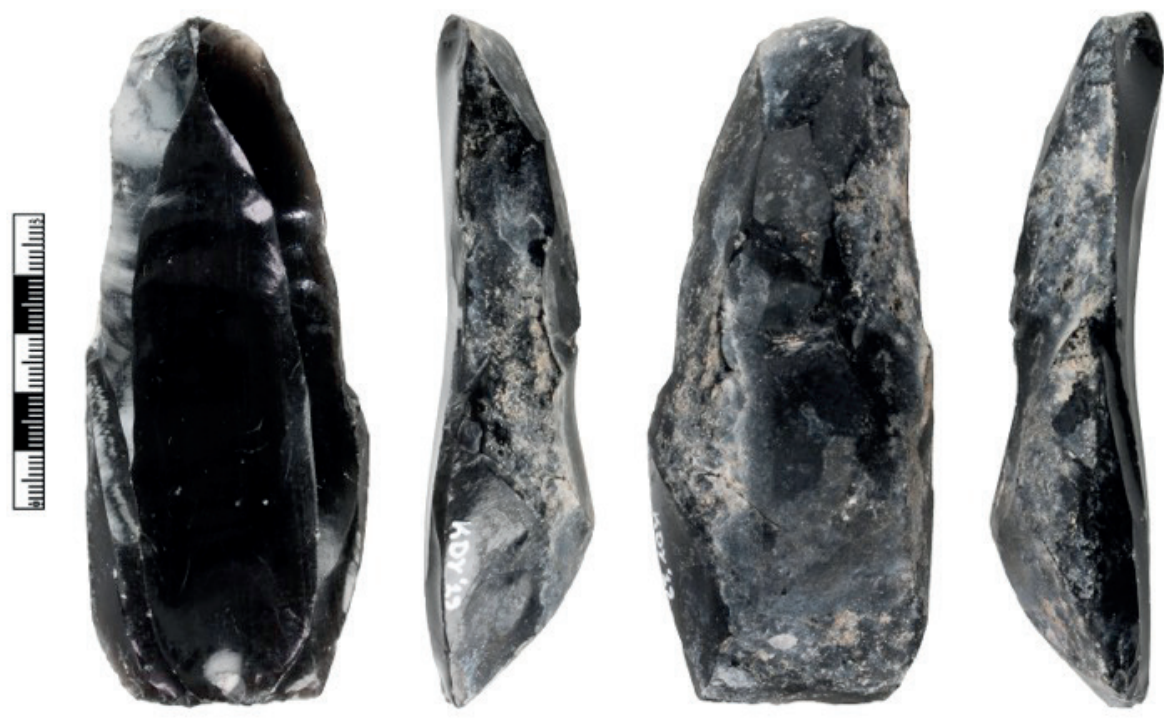

Figure 12. Bidirectional blade core (photo by Volkan Manap).

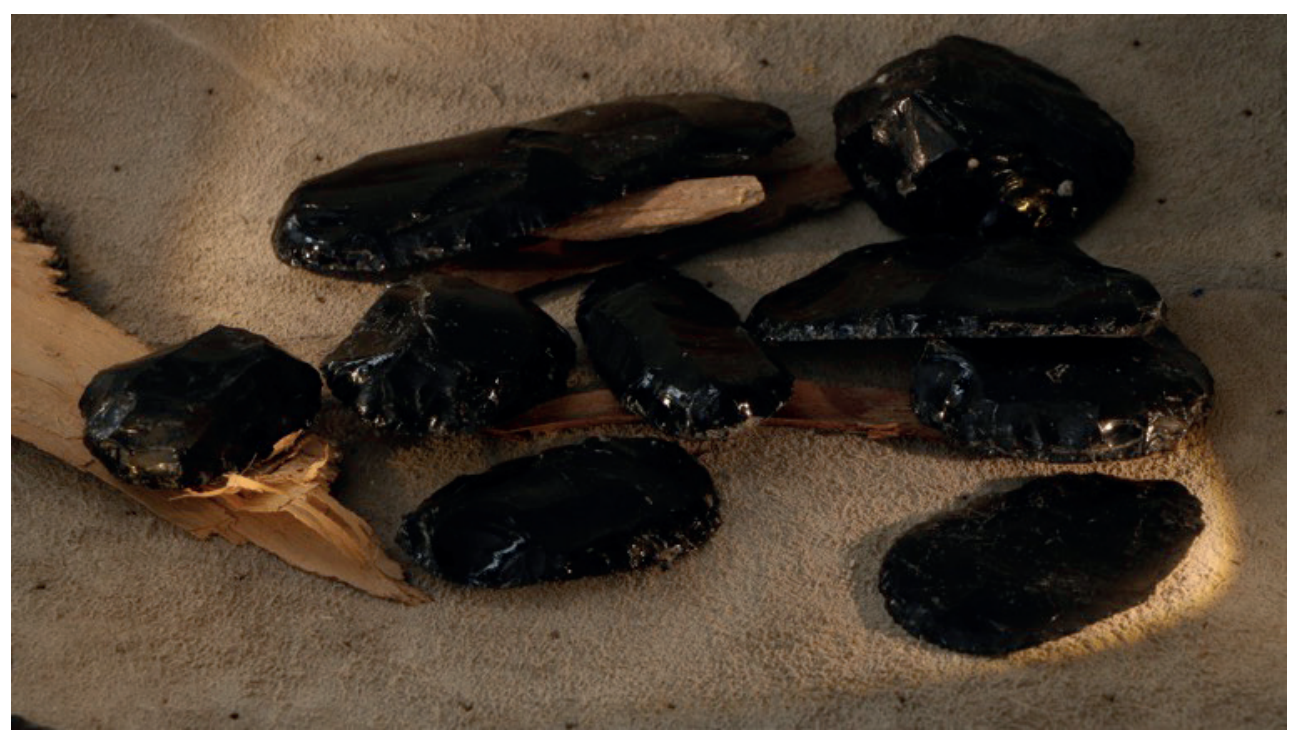

Figure 13. Obsidian scrapers (photo by Hale Tümer). 


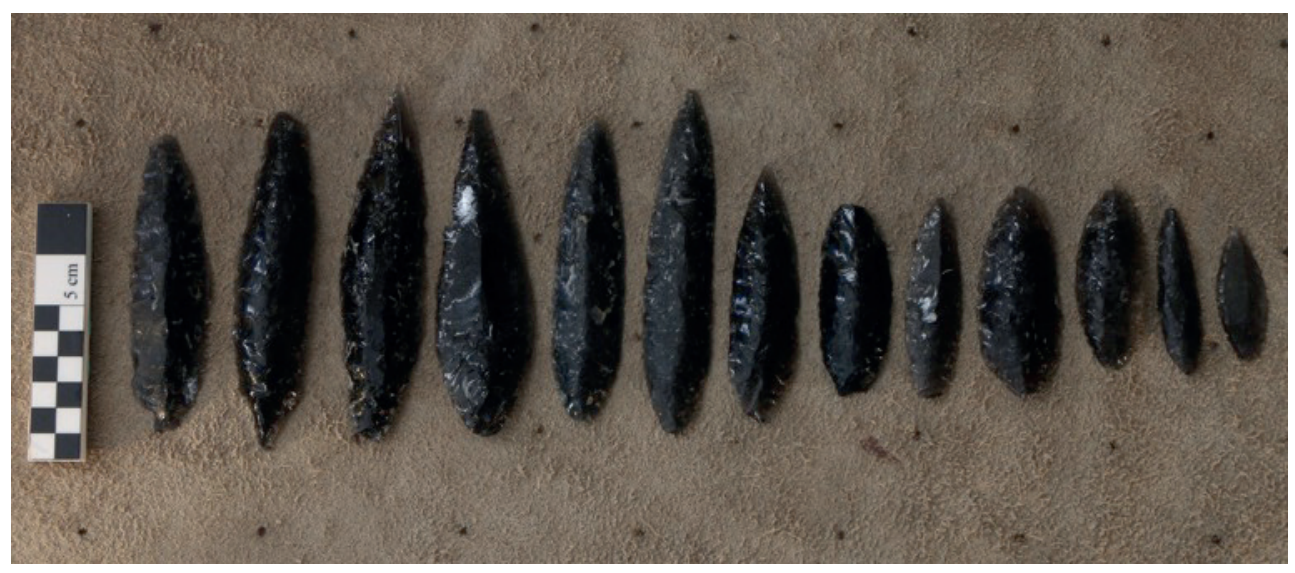

Figure 14. Obsidian pressure retouch oval arrowheads (photo by Hale Tümer).
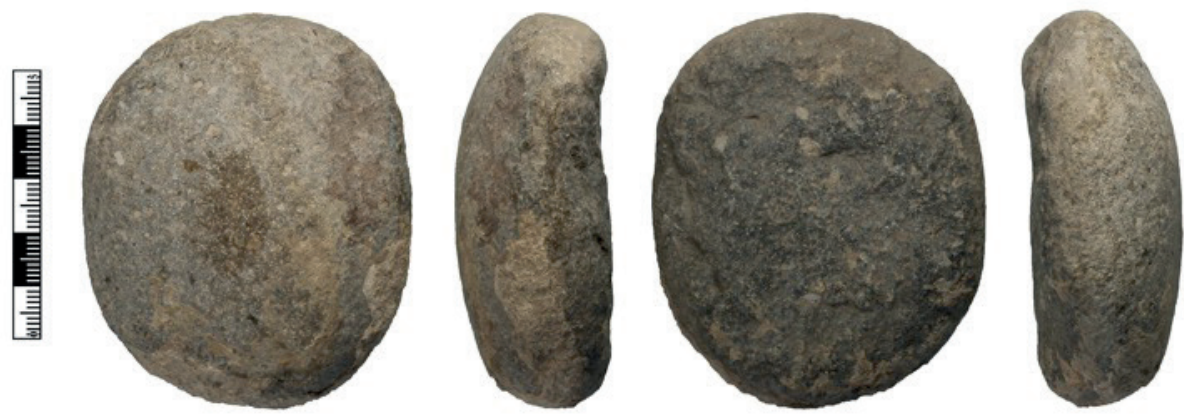

Figure 15. Example of hand-stone.

Figure 15: Example of hand-stone. 

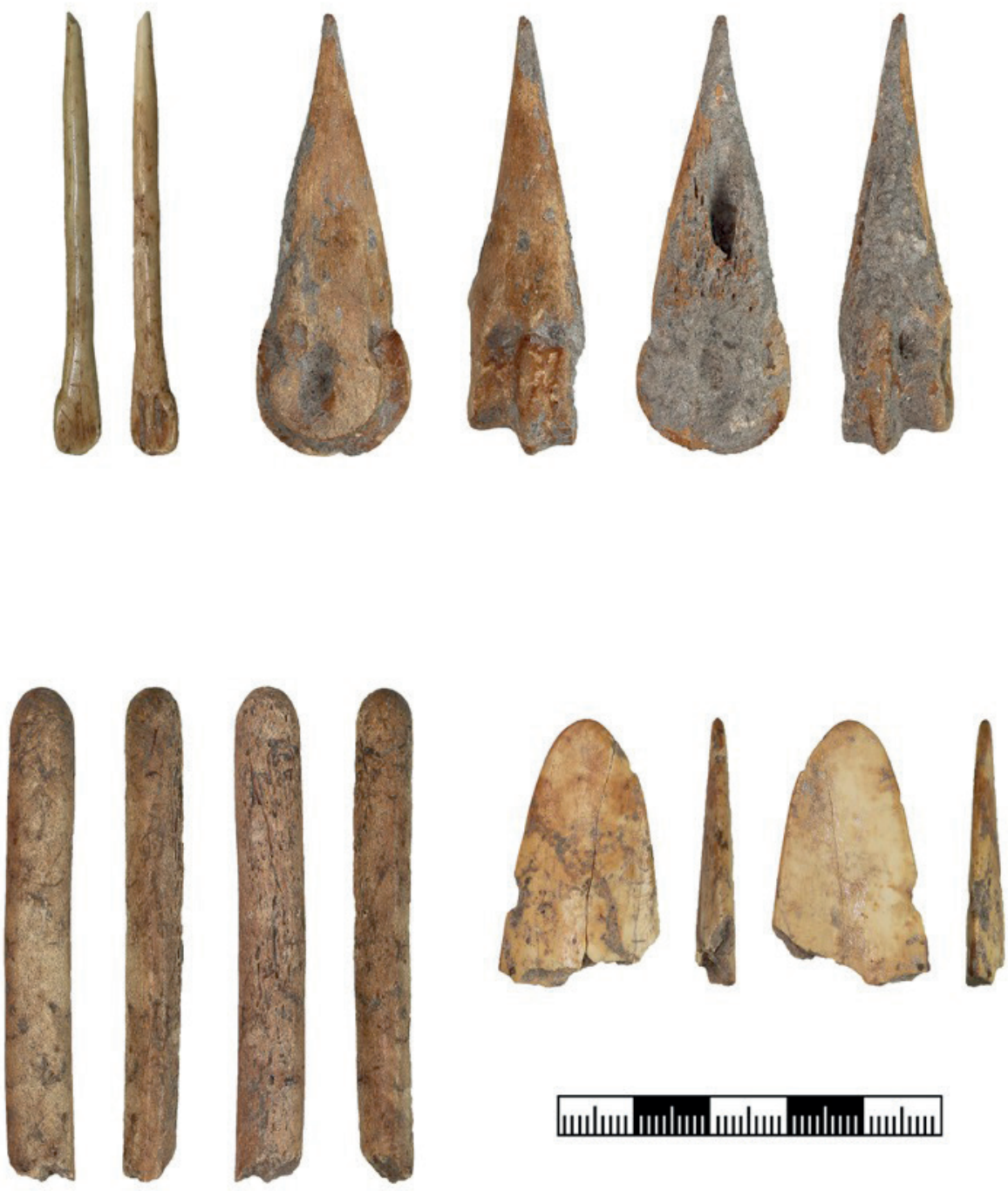

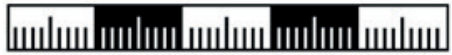

Figure 16. Examples of bone tools. 


\begin{tabular}{|l|l|l|l|l|l|}
\hline $\begin{array}{l}\text { Lab. } \\
\text { Number }\end{array}$ & Samples & Material & BP & cal. BC (2 sigma) & Probability \\
\hline $\begin{array}{l}\text { TUBITAK- } \\
\text { 0989 }\end{array}$ & SK 1 & Human & $8483 \pm 41$ & BC 7588-7498 & $95,40 \%$ \\
\hline $\begin{array}{l}\text { TUBITAK- } \\
\text { 0990 }\end{array}$ & SK 2 & & $8303 \pm 38$ & BC 7487-7253 & $89,50 \%$ \\
\cline { 5 - 7 }
\end{tabular}

Table 1. Radicarbon dates from the eastern slope of the mound.

\begin{tabular}{|c|c|c|c|c|c|c|c|c|c|c|c|c|c|c|}
\hline \multirow{2}{*}{\multicolumn{2}{|c|}{ Artefacts }} & 1080 & & & & 1084 & 1092 & 1088 & 1089 & 1085 & 1086 & 1087 & 1090 & 1091 \\
\hline & & KDY1 & KDY2 & KDY3 & KDY4 & KDY5 & KDY5b & KDY9 & KDY10 & KDY6 & KDY7 & KDY8 & KDY11 & KDY12 \\
\hline \multicolumn{2}{|c|}{ Nbr of analyses } & 3 & 1 & 2 & 1 & 1 & 1 & 1 & 1 & 1 & 1 & 1 & 1 & 2 \\
\hline \multicolumn{2}{|c|}{ Macroscopic charact. } & \multicolumn{6}{|c|}{ Grey translucent } & Opaque br & wn-black & \multicolumn{3}{|c|}{$\begin{array}{l}\text { Greyish green semi- } \\
\text { transporent to opaque }\end{array}$} & \multicolumn{2}{|c|}{ Grey translucent } \\
\hline \multicolumn{2}{|c|}{ Source } & \multicolumn{8}{|c|}{ Göllidaă East (GDG-4a,4b,-5) } & \multicolumn{3}{|c|}{ Nenezi } & \multicolumn{2}{|c|}{ Aclgöl East } \\
\hline A1203 & \%oxyde & 13,81 & 13,72 & 13,70 & 13,75 & 13,75 & 13,73 & 13,81 & 13,68 & 13,75 & 13,98 & 13,92 & 13,78 & 13,85 \\
\hline $\mathrm{SiO2}$ & $"$ & 74,51 & 74,39 & 74,40 & 74,38 & 74,47 & 74,28 & 74,48 & 74,21 & 74,07 & 74,40 & 74,50 & 74,27 & 74,34 \\
\hline$K 20$ & " & 4,58 & 4,54 & 4,58 & 4,43 & 4,54 & 4,44 & 4,48 & 4,26 & 4,12 & 4,37 & 4,39 & 4,48 & 4,45 \\
\hline $\mathrm{CaO}_{\mathrm{O}}$ & $"$ & 0,89 & 1,04 & 0,53 & 0,55 & 0,50 & 0,58 & 0,54 & 0,53 & 1,04 & 1,10 & 1,21 & 0,90 & 0,90 \\
\hline TiO2 & $"$ & 0,046 & 0,053 & 0,050 & 0,056 & 0,046 & 0,057 & 0,071 & 0,065 & 0,098 & 0,107 & 0,109 & 0,090 & 0,088 \\
\hline $\mathrm{MnO}$ & $"$ & 0,021 & 0,022 & 0,023 & 0,025 & 0,026 & 0,033 & 0,037 & 0,026 & 0,036 & 0,034 & 0,040 & 0,028 & 0,036 \\
\hline Fe203 & $"$ & 0,997 & 0,895 & 0,899 & 0,898 & 0,867 & 0,875 & 0,939 & 0,883 & 1,255 & 1,316 & 1,355 & 1,216 & 1,229 \\
\hline Cl & ppm & 662 & 659 & 581 & 1149 & 565 & 487 & 697 & 1391 & 1416 & 1523 & 1387 & 1264 & 1114 \\
\hline $\mathrm{Cr}$ & " & 58,0 & 51,9 & 59,7 & 54,0 & 55,0 & 57,0 & 53,5 & 56,1 & 60,3 & 67,6 & 55,6 & 61,6 & 63,9 \\
\hline $2 n$ & $"$ & $<100$ & 18,3 & 16,9 & 20,7 & 17,3 & 14,3 & 26,1 & 20,3 & 41,1 & 45,0 & 42,8 & 33,7 & 41,3 \\
\hline As & $"$ & 9,05 & 6 & 9,01 & 6,72 & 8,94 & 8,54 & 9,77 & 9,71 & $<\angle 0 D$ & 5,83 & 6,29 & 8,12 & $<100$ \\
\hline $\mathrm{Rb}$ & $"$ & 198,6 & 195,5 & 198,8 & 194,4 & 194,6 & 196,5 & 186,7 & 177,6 & 154,9 & 163,7 & 165,7 & 170,2 & 169,4 \\
\hline Sr & " & 17,21 & 6,91 & 6,85 & 6,77 & 7,01 & 9,59 & 11,01 & 8,80 & 74,42 & 78,30 & 79,24 & 59,24 & 60,54 \\
\hline y & $"$ & 15,35 & 13,71 & 13,15 & 14,52 & 14,44 & 14,13 & 13,04 & 13,96 & 12,26 & 12,67 & 12,35 & 12,70 & 12,97 \\
\hline Zr & " & 21,33 & 29,67 & 18,34 & 19,82 & 19,02 & 19,49 & 31,68 & 22,56 & 79,42 & 82,95 & 81,53 & 68,15 & 69,55 \\
\hline $\mathrm{Nb}$ & $"$ & 21,42 & 21,52 & 21,87 & 19,77 & 20,43 & 21,12 & 20,09 & 18,54 & 15,51 & 15,86 & 16,14 & 15,80 & 15,83 \\
\hline $\mathrm{Ba}$ & " & $\angle L O D$ & $<100$ & $<\angle O D$ & $<\angle 0 D$ & $\angle \angle O D$ & $<\angle O D$ & 72,26 & $<\angle O D$ & 310 & 280 & 254 & 167 & 299 \\
\hline Th & " & 19,55 & 22,79 & 22,16 & 18,45 & 21,76 & 18,83 & 20,54 & 20,73 & 22,96 & 26,57 & 28,68 & 29,05 & 29,15 \\
\hline U & $"$ & $\angle L O D$ & 7,74 & 7,65 & 8,61 & 7,80 & 9,07 & 7,60 & 8,22 & 9,00 & 8,64 & 9,13 & 7,82 & 9,60 \\
\hline $\mathrm{Pb}$ & " & 21,23 & 21,01 & 18,69 & 17,86 & 17,41 & 22,03 & 18,79 & 17,34 & 23,59 & 27,61 & 27,71 & 21,84 & 24,49 \\
\hline
\end{tabular}

Table 2. Portables XRF data of the 13 obsidian artefacts analysed with attribution to geological sources. 